\title{
Satellite image based quantification of invasion and patch dynamics of mesquite (Prosopis juliflora) in Great Rann of Kachchh, Kachchh Biosphere Reserve, Gujarat, India
}

\author{
S Vazeed Pasha ${ }^{1}$, K V Satish ${ }^{1}$, C Sudhakar Reddy ${ }^{1, *}$, P V V Prasada RaO ${ }^{2}$ and C S Jha ${ }^{1}$ \\ ${ }^{1}$ Forestry 83 Ecology Group, National Remote Sensing Centre, ISRO, Balanagar, Hyderabad 500 037, India. \\ ${ }^{2}$ Department of Environmental Sciences, Andhra University, Visakhapatnam 530 003, India. \\ ${ }^{*}$ Corresponding author. e-mail: drsudhakarreddy@gmail.com
}

The invasion of alien species is a significant threat to global biodiversity and the top driver of climate change. The present study was conducted in the Great Rann of Kachchh, part of Kachchh Biosphere Reserve, Gujarat, India, which has been severely affected by invasion of Prosopis juliflora. The invasive weed infestation has been identified using multi-temporal remote sensing datasets of 1977, 1990, 1999, 2005 and 2011. Spatial analyses of the transition matrix, extent of invasive colonies, patchiness, coalescence and rate of spread were carried out. During the study period of three and half decades, almost $295 \mathrm{~km}^{2}$ of the natural land cover was converted into Prosopis cover. This study has shown an increment of $42.9 \%$ of area under Prosopis cover in the Great Rann of Kachchh, part of the Kachchh Biosphere Reserve during 1977 to 2011. Spatial analysis indicates high occupancy of Prosopis cover with most of the invasion (95.9\%) occurring in the grasslands and only $4.1 \%$ in other land cover types. The process of Prosopis invasion shows high patch initiation, followed by coalescence, indicating aggressive colonization of species. The number of patches within an area of $<1 \mathrm{~km}^{2}$ increased from 1977 to 2011, indicating the formation of new Prosopis habitats by replacing the grasslands. The largest patch of Prosopis cover increased from $144 \mathrm{~km}^{2}$ in 1977 to $430 \mathrm{~km}^{2}$ in 2011 . The estimated mean patch size was $7.8 \mathrm{~km}^{2}$ in 1977 . The mean patch size was largest during 2011, i.e., $9 \mathrm{~km}^{2}$. The annual spread rate for Prosopis has been estimated as 2.1\% during 2005-2011. The present work has investigated the long term changes in Prosopis cover in the Great Rann of Kachchh, part of Kachchh Biosphere Reserve. The spatial database generated will be useful in preparing strategies for the management of Prosopis juliflora.

\section{Introduction}

Historical changes in land surface have impacted several aspects of ecosystems, resulting in climate change, biodiversity loss and fluctuation of biogeochemical and hydrological cycles (Mitsuda and Ito 2011). The biological invasion of alien species is recognized as the most serious threat to biodiversity and the top driver of global climate change (Mooney and Drake 1987;
Reddy 2008). The spatial information is considered necessary to develop policies aimed at invasive species management (Wittenberg and Cock 2001). There is an increasing attention on analysis of invasive species occurrence and distribution at the landscape level, at which spatial and temporal patterns of invasion can be linked to proximate causes, the rate of spread and the effectiveness of management practices (Robinson et al. 2008).

Keywords. Prosopis juliflora; mesquite; invasion; patch; coalescence; Kachchh; India. 
Remote sensing offers a cost effective means to study vegetation cover changes (Langley et al. 2001; Reddy et al. 2007). Because of the systematic observations at various scales, remote sensing extends possible data archives from present time to over few decades back (Xie et al. 2008). The efficacy of remote sensing data for detecting invasive plants depends on the sensor's spatial and spectral resolution. Accurate vegetation classification from a multispectral image is dependent on the degree of spectral reflectance by a range of factors including leaf chemistry, canopy structure and density (Lymburner et al. 2000). Satellite imagery offers the ability to efficiently map canopy dominating invasive woody species, which have reflectance characteristics that are distinct from other vegetation (Lamb and Brown 2001). Of late, there is an increase in the number of studies dealing with the application of remote sensing and GIS in the mapping of invasive species and their distribution and modelling (Joshi et al. 2004). However, in India, little effort has been given to map the invasive alien species and areas vulnerable to invasion.

As many as 173 invasive alien plant species have been reported in India (Reddy 2008). Prosopis juliflora (Sw.) DC. (syn. Prosopis chilensis (Molina) Stuntz) popularly known as 'mesquite' native to Central and South America is now found throughout the semi-arid and arid tropics. Prosopis juliflora is a major canopy dominating invasive shrub species in India and has also invaded other regions throughout the world including Saharan and southern Africa, Australia, Middle East, Pakistan and Hawaii where it strongly suppresses species native to those regions, resulting in serious environmental and social costs (Pasiecznik et al. 2001; Goslee et al. 2003). IUCN has rated Prosopis juliflora as one of the world's top 100 invasive alien species (IUCN 2009). It grows in varied types of soils from sandy to saline-alkaline soils. It has proved to be a versatile species for afforesting shifting sand dunes, coastal dunes, river beds, salinealkaline lands, eroded hill slopes, mine-spoiled areas and other wastelands. Prosopis juliflora has now become the main source of fuel in rural areas, fulfilling more than $70 \%$ of the firewood requirements of rural people in the tropical arid and semiarid zones of India. The seed pod is used as a livestock feed and the wood is also used in charcoal making (Muthana and Arora 1983).

The first recorded introduction of Prosopis juliflora in India was in 1877 from Latin America, in Cuddapah district of Andhra Pradesh (Reddy 1978). It was introduced into parts of Gujarat in 1882 (FAO 1998). Gujarat State Forest Department initially planted about $315.5 \mathrm{~km}^{2}$ exclusively of Prosopis juliflora as a measure to check the advancement of the Rann during1960-1961.
The most abundant distribution of Prosopis juliflora is recorded in arid and semi-arid zones of India covering Kachchh region of Gujarat, arid western part of Rajasthan, parts of Uttar Pradesh, Haryana, Maharashtra, Karnataka, Tamil Nadu and Andhra Pradesh (FAO 1998). Champion and Seth (1968) have mentioned that Prosopis juliflora is spreading rapidly in Rann of Kachchh, imparting characteristic physiognomy and considered desirable to erect a separate subtype in Rann saline thorn scrub.

Venugopal (1998) has used SPOT multitemporal data to monitor the infestation of water hyacinth (Eichhornia crassipes) using Normalised Difference Vegetation Index. Joshi et al. (2004) have reviewed remote sensing techniques to map canopy dominant invasive species and possibilities to map noncanopy invasive species. Anderson et al. (1993) mapped Ericameria austrotexana infestation in a large homogenous area using Landsat TM imagery. The ability of the Landsat data to map the extent of Prosopis in parts of South Africa has demonstrated a high degree $(72 \%)$ of accuracy (Berg et al. 2013). The present study has been carried out in Great Rann of Kachchh region to address spatial dynamics of Prosopis juliflora using remote sensing and GIS techniques. The study also aims to address delineation of spatial extent of Prosopis juliflora to assess the severity of invasion, patch dynamics and rate of spread using multi-temporal satellite data over three and half decades (1977-2011).

\section{Study area}

Great Rann of Kachchh region is located in the northwestern, north and northeastern parts of Kachchh mainland-Kachchh district in Gujarat state, India (figure 1). It includes Kachchh Desert Wildlife Sanctuary (total geographical area: $7505.22 \mathrm{~km}^{2}$ ) and forms part of Kachchh Biosphere Reserve (total geographical area: 12,454 $\mathrm{km}^{2}$ ). The area represents a unique combination of saline deserts (white desert), seasonal wetlands and the eastern part of little Banni. It represents the only area in India where flamingo congregate in enormous numbers to breed and is referred as 'Flamingo city'. The climate is arid and the rainfall extremely erratic and variable in distribution, both in time and space. The total annual rainfall, occurring through southwest monsoon between June and September, is very low with an average of $300 \mathrm{~mm}$ per year with a coefficient of variation of $65 \%$. The average maximum temperature is $42^{\circ} \mathrm{C}$, the average minimum temperature is about $12^{\circ} \mathrm{C}$ and average relative humidity is about $25 \%$. However, maximum temperature as high as $50^{\circ} \mathrm{C}$ and 


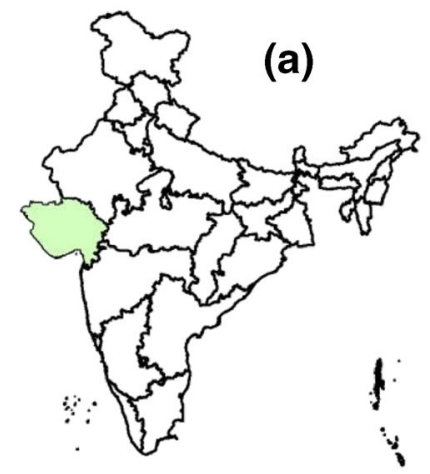

$68^{\circ} 0^{\prime} 0^{\prime \prime E} \quad 70^{\circ} 0^{\prime} 0^{\prime \prime} \mathrm{E}$

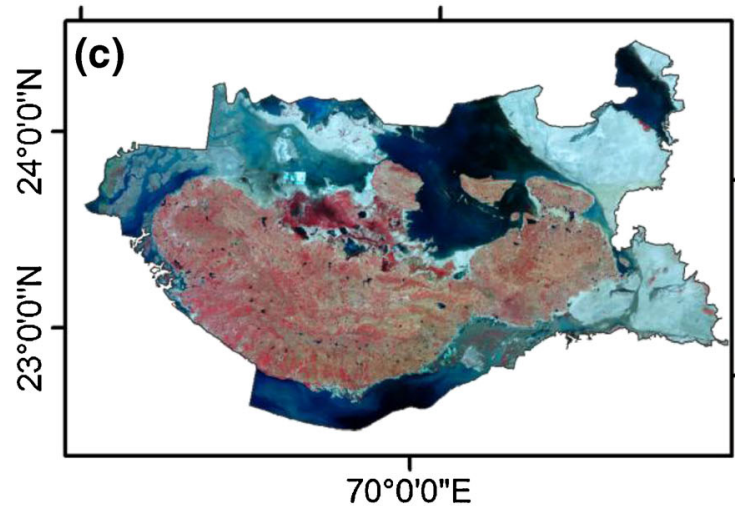

(a) Gujarat in India

(b) Kachchh district in Gujarat

(c) IRS P6 AWiFS FCC image of Kachchh district showing Rann ecosystem

(d) IRS P6 AWiFS FCC image showing

Kachchh Biopshere Reserve

1. Great Rann of Kachchh

2. Little Rann of Kachchh

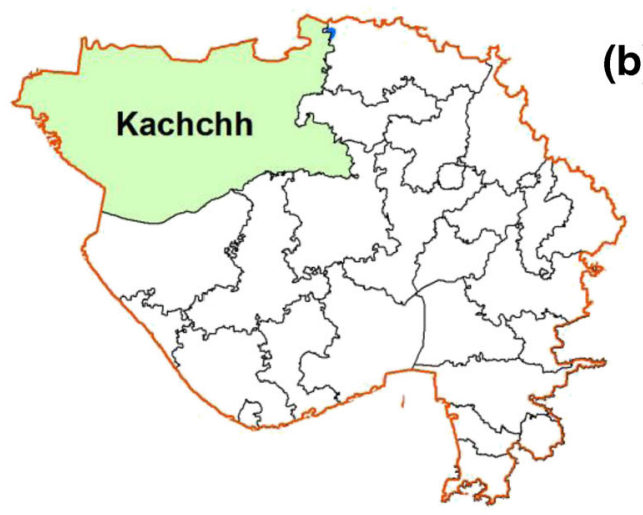

(b)

$\bigwedge^{N}$

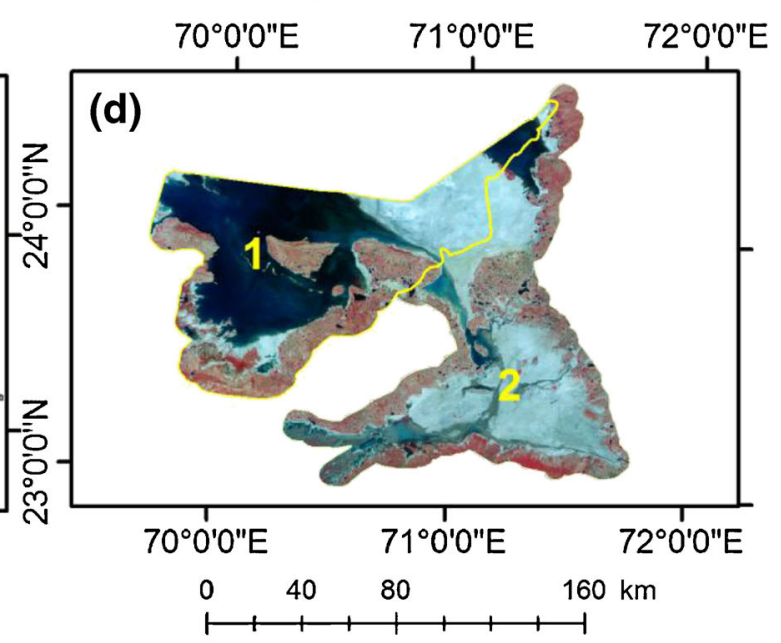

Figure 1. Location map of Great Rann of Kachchh (GRK) in Kachchh Biosphere Reserve, Gujarat, India.

minimum temperature as low as $0^{\circ} \mathrm{C}$ has also been recorded. The area has the highest rate of evaporation in the country. The Rann may experience unseasonal rains or violent southwest winds at anytime. Topography of Great Rann of Kachchh rises from altitude of 0-458 $\mathrm{m}$. The highest peak in Kachchh is Kalodungar hill at an altitude of $458 \mathrm{~m}$ (Anonymous 2005).

\section{Data used}

The multi-spectral Landsat MSS data of 17 January 1977, Landsat TM of 2 November 1990, Landsat ETM+ of 18 October 1999, IRS P6 LISS-III of 9 October 2005, 26 March 2006 and 18 December 2011 were analysed. Survey of India topographical maps and multi-season IRS P6 AWiFS images of 2005 and 2012 were used as ancillary data.

\section{Methodology}

Image to image registration was performed using GCPs selected from ortho-rectified Landsat TM data (http://glcf.umd.edu/research/portal/ geocover/) using a first order polynomial transformation. Datasets were corrected with a root-meansquare error of $<1$ pixels for all data. The images were georeferenced to the Universal Transverse Mercator coordinate system and WGS84 datum. To reduce the error due to various atmospheric conditions, Top-of-Atmosphere reflectance was performed on multi-temporal remote sensing datasets (Chavez 1996).

Different land use/land cover categories and areas with infestation of Prosopis juliflora cover were surveyed using Global Positioning System during 2012 and 2013. The information collected 
from the field was entered into a Geographic Information System. The on-screen visual interpretation technique was used to map land use/land cover types on multi-temporal satellite data. In the study area, Prosopis juliflora remained evergreen throughout the year, while grasslands and thorn scrub vegetation types showed senescence/deciduousness. Prosopis cover shows dark red, brownish red and dark pink tone in the standard false colour composite images depending on its date of acquisition.

Spatial analysis was carried out in three different phases. Phase 1 assesses the total net area under each land cover category. Phase 2 analyses the land cover conversions between categories by change area transition matrix with reference to Prosopis juliflora. Phase 3 has identified the spatial tracking of extent of invasive colonies and rate of spread of Prosopis juliflora to analyse the impact of invasion. ERDAS Imagine and ArcGIS were used for digital image processing and GIS respectively. Using GIS spatial analyses, Prosopis patch

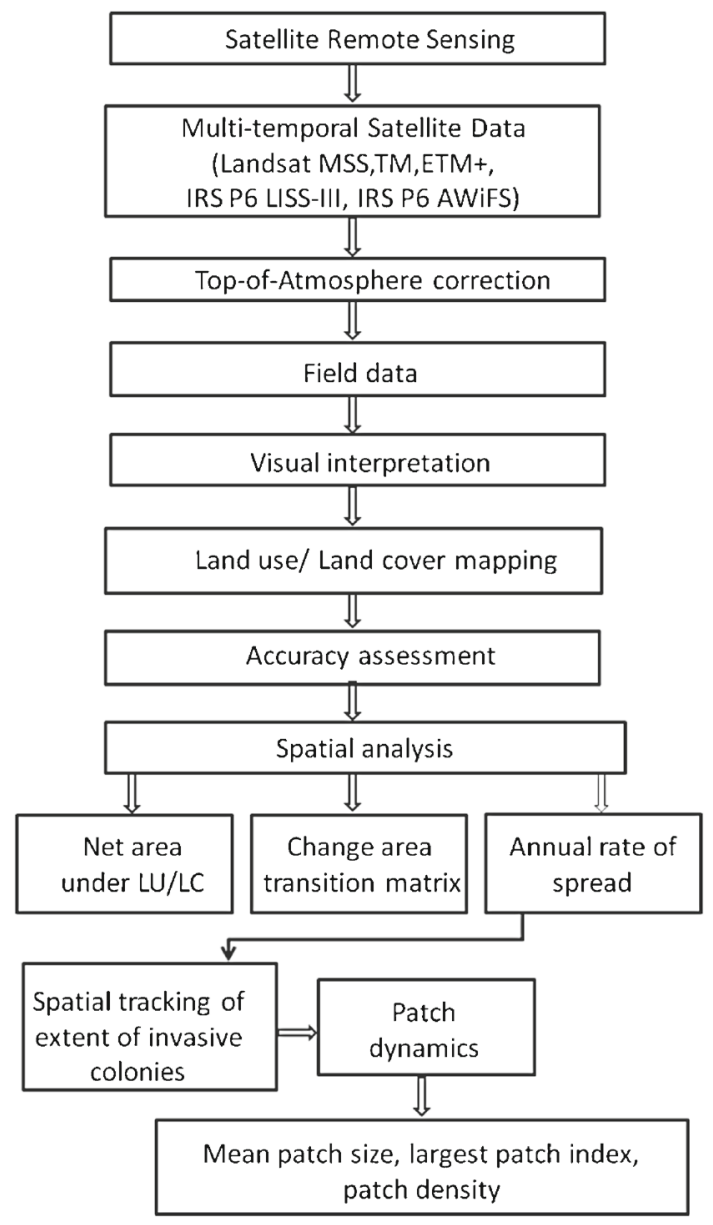

Figure 2. Flow chart showing methodology used in the study. dynamics were computed based on mean patch size, largest patch index and patch density. The annual rate of Prosopis cover change is derived from the compound interest formula (Puyravaud 2003).

$$
r=\frac{1}{\left(t_{2}-t_{1}\right)} \times \ln \frac{a_{2}}{a_{1}}
$$

where $r$ is the annual rate of change (percentage per year), $a_{1}$ and $a_{2}$ are the area estimates at time $t_{1}$ and $t_{2}$, respectively.

Quantitative assessment of the accuracy of mapping for Prosopis classification and other land covers in the study area was undertaken (Landis and Koch 1977; Congalton and Green 1999). To assess the accuracy of Prosopis classification, a total of 300 points were generated randomly on the classified map and verified in the field. It was performed by determining the percentage relationship between Prosopis presence observed in the field and that classified based on visual image interpretation technique in an error matrix (confusion matrix). Outline of methodology was presented in figure 2.

\section{Results and discussion}

\subsection{Quantification of Prosopis spread}

Seven land cover types identified in the study were analysed and the area statistics was derived from classified maps (figure 3 ). The area under study is predominantly a wetland which occupies $2 / 3^{\text {rd }}$ of total geographical area of Great Rann of Kachchh in Kachchh Biosphere Reserve. Thorn scrub is mixed type represented by Euphorbia caducifolia, Capparis decidua, Grewia tenax, Commiphora wightii, Salvadora oleoides and Mimosa hamata. Prosopis scrub is a gregarious type and mainly constitutes Prosopis juliflora as the canopy dominating species. The results confirm that land cover in the Great Rann of Kachchh, Kachchh Biosphere Reserve has changed significantly since 1977 with grassland being transformed to Prosopis scrub. Prosopis invasion follows a process of high patch initiation, followed by coalescence, rate of spread with the maximum quantity of recruitment and coalescence. It has formed mono-specific thickets in the grasslands. Coalescence of Prosopis cover has increased in the study area since 1977 (figure 4; table 1). Analysis indicates increase of $42.9 \%$ of area under Prosopis cover during 1977-2011.

During the period of analysis (1977-2011), almost $295 \mathrm{~km}^{2}$ of the natural land cover has been converted to Prosopis cover (figures 4 and 5). Spatial analysis indicates that Prosopis cover was highly dispersed with most of the invasion (95.9\%) 


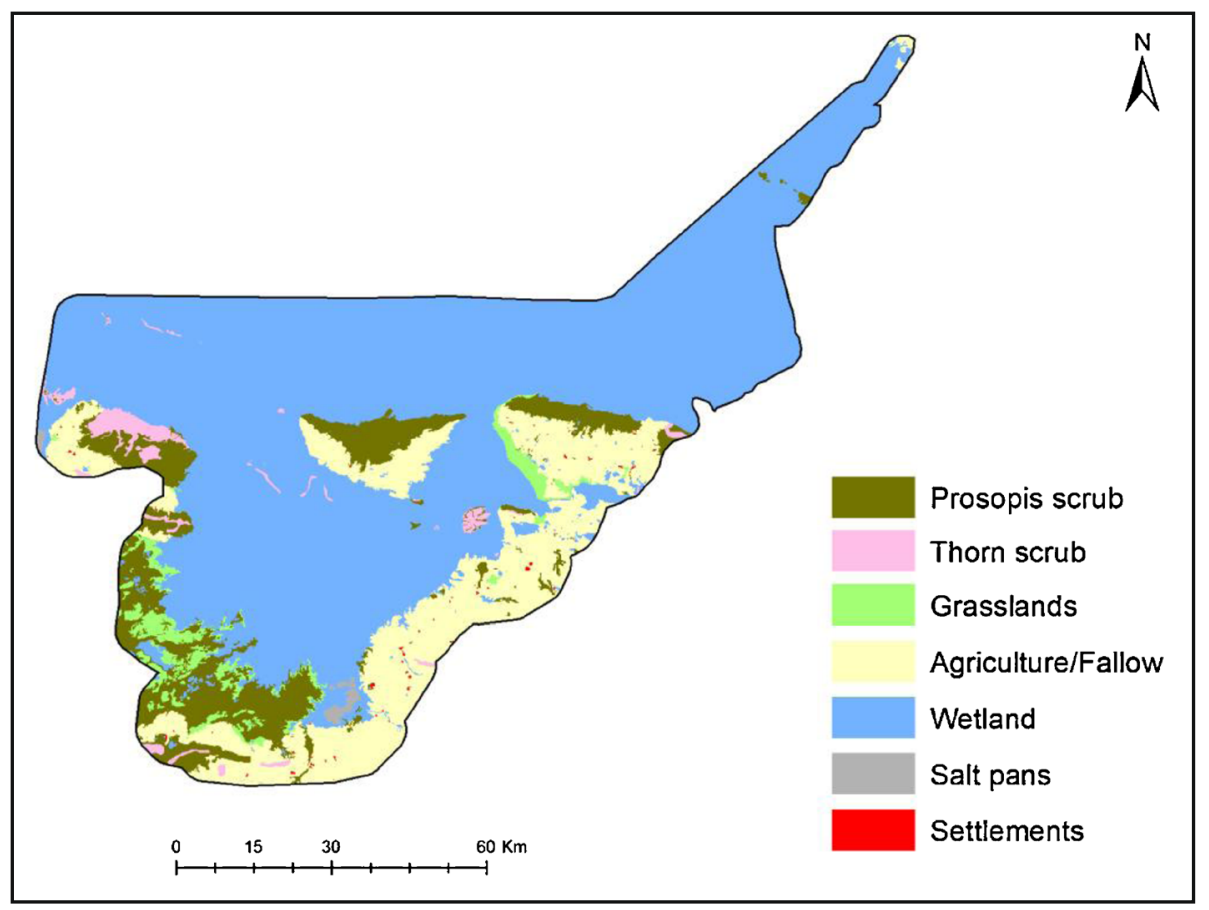

Figure 3. Classified map showing distribution of land use/land cover (LU/LC) in Great Rann of Kachchh, Kachchh Biosphere Reserve: 2011.

occurring in the grasslands and only $4.1 \%$ outside of grasslands. About $56.3 \%$ area of grassland was reduced during 1977 to 2011 (figure 6). Table 2 clearly indicates rapid spread of Prosopis cover in the Kachcch landscape preferring grasslands rather than thorn scrub and wetlands. There was a decline in grassland area which was recorded as $283 \mathrm{~km}^{2}$. About $9 \mathrm{~km}^{2}$ of wetland was converted to Prosopis scrub in the period of 1977 to 2011, indicating wider adaptability and invasive nature of the species.

\subsection{Patch dynamics}

Spatial and temporal dynamic analysis through patch level understanding elucidates the recruitment of new plant patches and coalescence of expanding patches. Prosopis invasion shows high patch initiation followed by coalescence as observed by Robinson et al. (2008). There has been a significant change in the number of patches of Prosopis. There were 87 patches of Prosopis in the study area during 1977 showing expanding trend in the following years (figure 6; table 3 ). The coalescence in Prosopis scrub decreased from 125 patches to 108 patches which may be attributed to joining of fragments. The number of small patches $\left(<1 \mathrm{~km}^{2}\right)$ has been increasing from 1977 to 2011, indicating colonization of new invasive colonies. The patches in Khadir Bet almost showed stabilization and reached a climax while other patches of Prosopis in southern part of study area, i.e., parts of little Banni showed very high spatial dynamics conversely leading to patch succession and coalescence.

Prosopis as an aggressive coloniser has been increasing its largest patch from $144 \mathrm{~km}^{2}$ in 1977 to $430 \mathrm{~km}^{2}$ over the past 35 years. The largest Prosopis patch delineated during 1990, 1999 and 2005 period was 186, 190 and $209 \mathrm{~km}^{2}$ respectively. Accordingly, largest patch index was very high (44.3) during 2011, followed by 24.4 in 2005 . The minimum largest patch index was 21.2 during 1977. The mean patch size was $7.8 \mathrm{~km}^{2}$ in 1977 and the explicit mean patch size was very high during 2011 and reached $9 \mathrm{~km}^{2}$ by 2011 (figure 7).

\subsection{Spatio-temporal pattern of invasion}

Presently, Prosopis juliflora dominates the landscape of Rann ecosystem forming homogeneous patches. The total area of Prosopis infestation mapped for the year 2011 was $971 \mathrm{~km}^{2}$, which is significantly high as compared to 1977 . The annual spread rate for Prosopis as per compound interest formula has been estimated as $1.2 \%$ during $1977-$ 1990, 0.4\% during 1990-1999, 0.6\% during 19992005 and $2.1 \%$ during 2005-2011 (figure 8). Overall annual rate of spread for Prosopis was 1\% for the last three and half decades.

The study by Sastry et al. (2003) has recorded 9.85\% of the area under Prosopis cover in Banni grasslands during 1980 and predicted its spread 


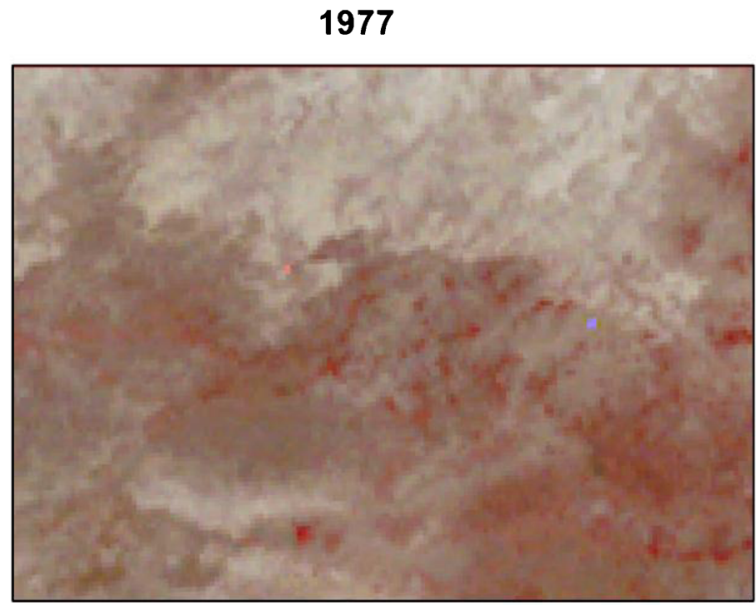

1999

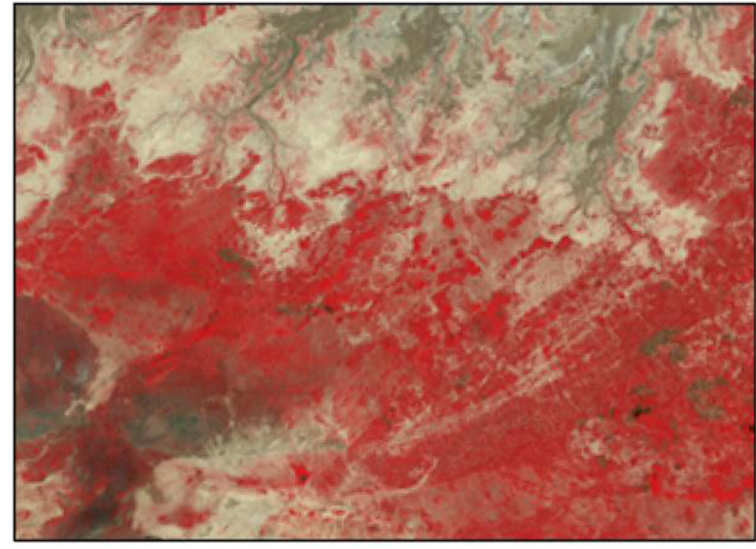

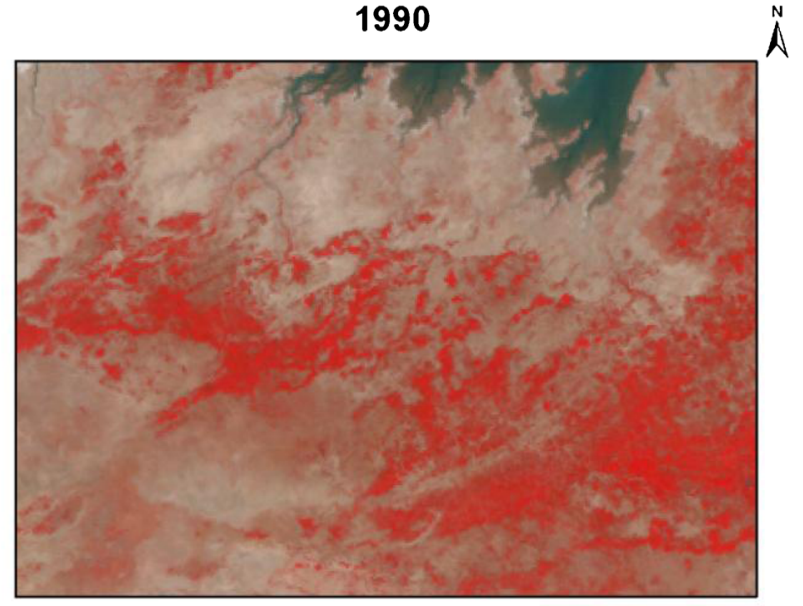

2011

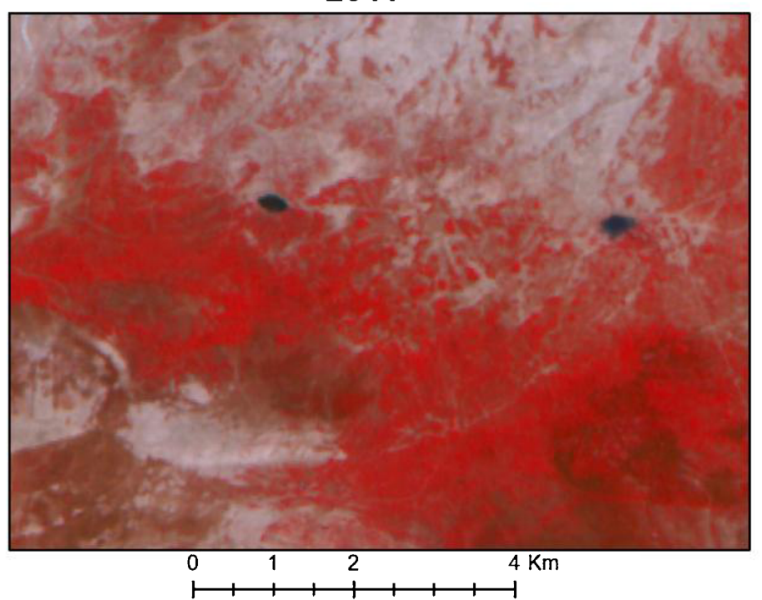

Figure 4. False colour composite images of southern part of Great Rann of Kachchh, Kachchh Biosphere Reserve showing expansion of Prosopis in different time periods.

Table 1. Areal extent of land use/land cover of Great Rann of Kachchh, Kachchh Biosphere Reserve (area in km ${ }^{2}$ ).

\begin{tabular}{|c|c|c|c|c|c|c|c|c|c|c|}
\hline \multirow[b]{2}{*}{ Class } & \multicolumn{2}{|c|}{1977} & \multicolumn{2}{|c|}{1990} & \multicolumn{2}{|c|}{1999} & \multicolumn{2}{|c|}{2005} & \multicolumn{2}{|c|}{2011} \\
\hline & Area & $\%$ of area & Area & $\%$ of area & Area & $\%$ of area & Area & $\%$ of area & Area & $\%$ of area \\
\hline Thorn scrub & 160 & 1.7 & 157 & 1.6 & 158 & 1.7 & 158 & 1.7 & 159 & 1.7 \\
\hline Prosopis scrub & 679 & 7.1 & 797 & 8.4 & 827 & 8.7 & 855 & 9.0 & 971 & 10.2 \\
\hline Grasslands & 612 & 6.4 & 467 & 4.9 & 446 & 4.7 & 392 & 4.1 & 268 & 2.8 \\
\hline Agriculture/fallow & 1679 & 17.6 & 1665 & 17.4 & 1655 & 17.3 & 1649 & 17.3 & 1649 & 17.3 \\
\hline Wetland & 6402 & 67.1 & 6447 & 67.6 & 6432 & 67.4 & 6456 & 67.7 & 6455 & 67.6 \\
\hline Settlements & 10 & 0.1 & 10 & 0.1 & 11 & 0.1 & 11 & 0.1 & 11 & 0.1 \\
\hline Salt pans & 0 & 0 & 0 & 0.0 & 15 & 0.2 & 20 & 0.2 & 31 & 0.3 \\
\hline Grand total & 9543 & 100 & 9543 & 100 & 9543 & 100 & 9543 & 100 & 9543 & 100 \\
\hline
\end{tabular}

further to $31.23 \%$ of area by 1998 . It has been recorded that area under Prosopis has increased from 378 to $684 \mathrm{~km}^{2}$ (an $81 \%$ increase) during 1980-1992 in Banni grassland (FAO 1998) is expanding at a rate of about $25 \mathrm{~km}^{2}$ per year. Based on present study covering Great Rann of Kachchh, part of Kachchh Biosphere Reserve, its expansion during 2005 to 2011 was $19.2 \mathrm{~km}^{2}$ per year. In previous periods its expansion was $9 \mathrm{~km}^{2}$ per year during 1977-1990, $3.3 \mathrm{~km}^{2}$ during 19901999 and $4.8 \mathrm{~km}^{2}$ during 2000-2005. Hence it is clear that spread and dominance of Prosopis in the study area is related to the factors of successive droughts, increasing salinity and intense livestock pressure.

The annual rate of expansion of Prosopis in Banni grassland is about $44.8 \mathrm{~km}^{2} /$ year (Jadhav et al. 1992). The studies by GUIDE (1999) and 


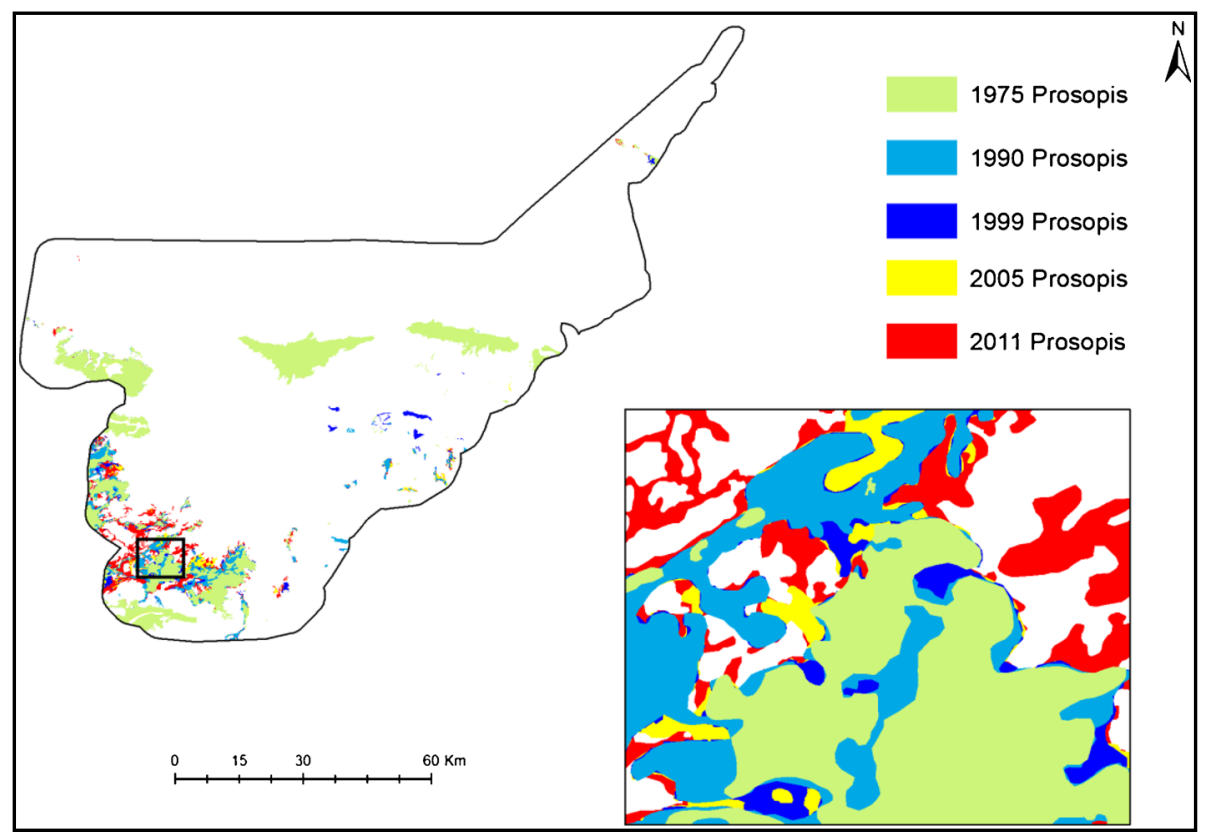

Figure 5. Classified map showing spatial expansion of Prosopis in different time periods.

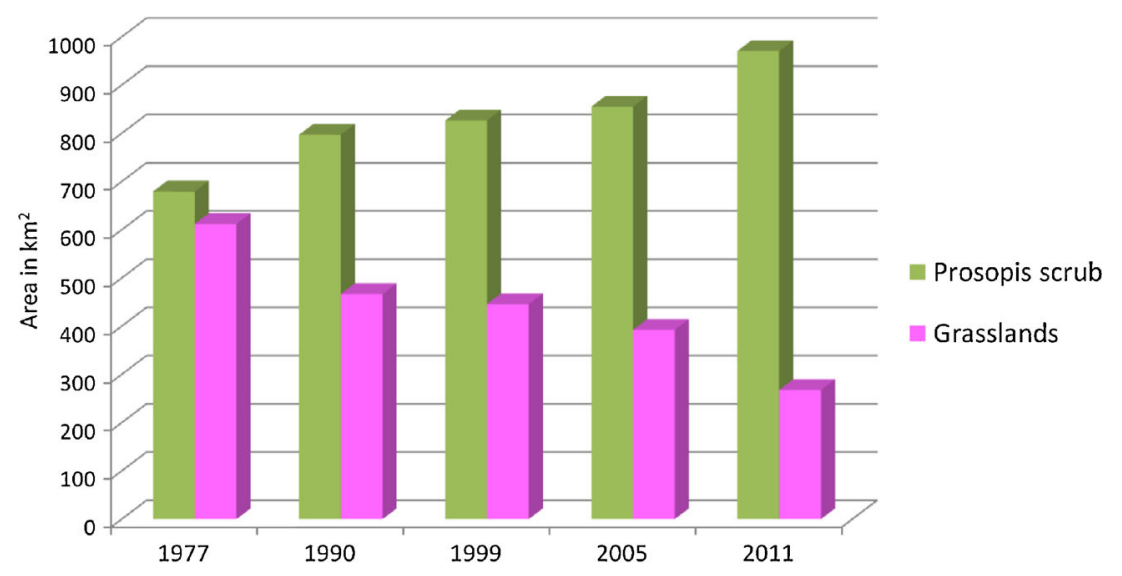

Figure 6. Changing spatial pattern of Prosopis scrub and grasslands.

Table 2. Transition matrix for invasion of Prosopis in land cover types of Great Rann of Kachchh, Kachchh Biosphere Reserve (area in $\mathrm{km}^{2}$ ).

\begin{tabular}{lrcccc}
\hline Change class & $1977-1990$ & $1990-1999$ & $1999-2005$ & $2005-2011$ & $1977-2011$ \\
\hline Thorn scrub & 2 & 0 & 1 & 0 & 3 \\
Grasslands & 114 & 26 & 25 & 118 & 283 \\
Wetland & 1 & 4 & 3 & 1 & 9 \\
Grand total & 118 & 30 & 29 & 119 & 295 \\
\hline
\end{tabular}

Shah and Somusundaram (2010) have reported that the area under Prosopis dominance during 1997 of about $6 \%$ and in 2008 it increased to $27.5 \%$ of the total area of Banni. The result clearly indicates that the grass cover has reduced and the Prosopis dominant area has increased between 1999 and 2008. One of the recent studies showed that $45 \%$ of area in Banni is falling under Prosopis cover (Shah and Somusundaram 2010) and it shows a very alarming situation for Banni grasslands. The phase-wise removal of Prosopis will give a better conservation measure for the grassland restoration (GUIDE 1999). The study has found that invasive species populations can be detected only after they 
Table 3. Patchiness of invasive colonies of Prosopis juliflora (area in $\mathrm{km}^{2}$ ).

\begin{tabular}{|c|c|c|c|c|c|c|c|c|c|c|c|}
\hline \multirow[b]{2}{*}{ Sl. no. } & \multirow[b]{2}{*}{$\begin{array}{c}\text { Patch size } \\
\left(\mathrm{km}^{2}\right)\end{array}$} & \multicolumn{2}{|c|}{1977} & \multicolumn{2}{|c|}{1990} & \multicolumn{2}{|c|}{1999} & \multicolumn{2}{|c|}{2005} & \multicolumn{2}{|c|}{2011} \\
\hline & & $\begin{array}{l}\text { No. of } \\
\text { patches }\end{array}$ & Area & $\begin{array}{l}\text { No. of } \\
\text { patches }\end{array}$ & Area & $\begin{array}{l}\text { No. of } \\
\text { patches }\end{array}$ & Area & $\begin{array}{l}\text { No. of } \\
\text { patches }\end{array}$ & Area & $\begin{array}{c}\text { No. of } \\
\text { patches }\end{array}$ & Area \\
\hline 1 & $<1$ & 60 & 12 & 72 & 17 & 86 & 24 & 89 & 25 & 97 & 71 \\
\hline 2 & $1-10$ & 18 & 41 & 25 & 67 & 24 & 69 & 26 & 75 & 4 & 27 \\
\hline 3 & $10-50$ & 4 & 90 & 5 & 117 & 5 & 135 & 5 & 138 & 2 & 34 \\
\hline 4 & $50-100$ & 2 & 151 & 2 & 151 & 2 & 150 & 2 & 150 & 2 & 150 \\
\hline 5 & $>100$ & 3 & 385 & 3 & 444 & 3 & 449 & 3 & 467 & 3 & 688 \\
\hline \multicolumn{2}{|c|}{ Grand total } & 87 & 679 & 107 & 797 & 120 & 826 & 125 & 855 & 108 & 971 \\
\hline
\end{tabular}

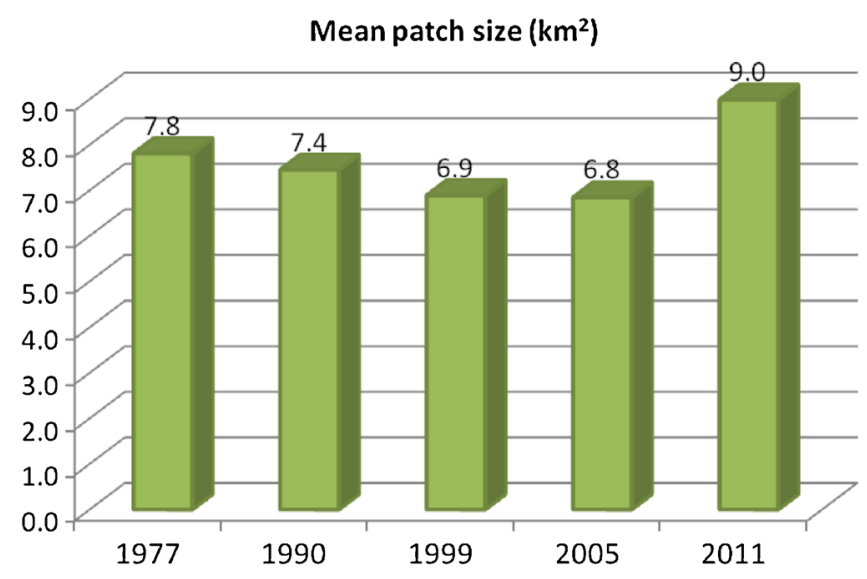

Figure 7. Mean patch size of Prosopis juliflora: 1977-2011.

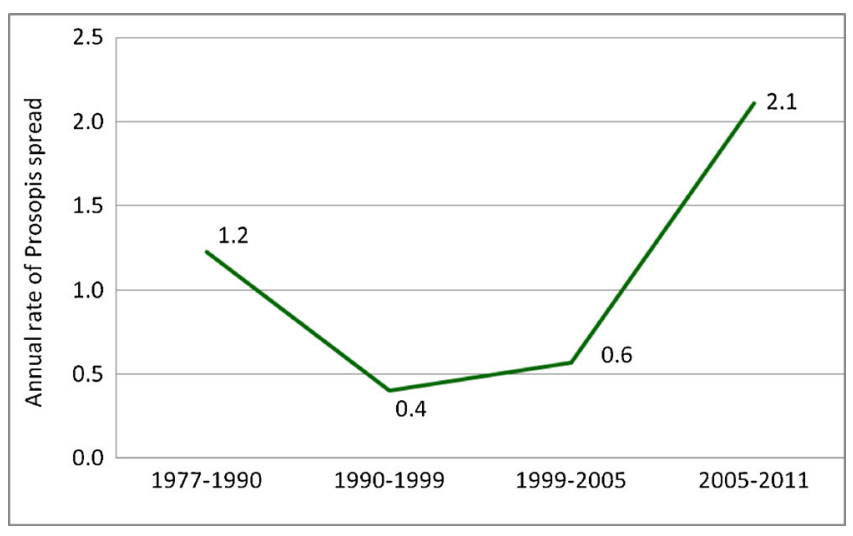

Figure 8. Annual rate of spread of Prosopis juliflora: 19772011.

become dense and widespread. According to the study in southern Gujarat, Prosopis cover represents an area of $257 \mathrm{~km}^{2}$ which occupies $4 \%$ of total vegetation area in 2006 (Bhatt et al. 2013).

Overall accuracy summarizes the total agreement/disagreement between the classified maps. It incorporates major diagonals and excludes error of commission and error of omission. In the present study, overall classification accuracy for Prosopis cover mapping has been assessed as $92.7 \%$ (table 4) and kappa coefficient of 0.86 for the period of 2011 . The omission error $(8.7 \%)$ describes the number of
Table 4. Error matrix of the relationship between reference data and the result of the IRS P6 LISS III image interpretation (2011).

\begin{tabular}{lcccc}
\hline Classification & $\begin{array}{c}\text { Prosopis } \\
\text { present }\end{array}$ & $\begin{array}{c}\text { Prosopis } \\
\text { absent }\end{array}$ & $\begin{array}{c}\text { Row } \\
\text { total }\end{array}$ & $\begin{array}{c}\text { Producer } \\
\text { accuracy }\end{array}$ \\
\hline Prosopis present & 141 & 9 & 150 & 94.0 \\
Prosopis absent & 13 & 137 & 150 & 91.3 \\
Column total & 154 & 146 & 300 & \\
User accuracy & 91.6 & 93.8 & & \\
\hline
\end{tabular}

points that should have been classified as Prosopis but were omitted from the class. The commission error $(6 \%)$ describes the number of points that were classified as Prosopis but in reality belong to other classes.

This invasive species is both beneficial and harmful (Tessema 2012). Leaves of mesquite contain a greater amount of inhibitors and suppress and replace the indigenous biodiversity (Getachew et al. 2012). Mesquite has replaced large areas of grasslands by aggressive colonization and allelopathic effects. It starts branching closer to the ground which makes under canopy seedling establishment of other species very difficult. Several areas of grasslands and agricultural fields are now being invaded reducing the livestock population in the study area. Being a drought tolerant, Prosopis is providing socioeconomic benefits as it is able to grow well on arid saline lands. It has soil binding capacity. In Gujarat, farmers raise Prosopis along field boundaries to meet fuel wood requirements (Saxena and Venkateshwarlu 1991). The poor women in northwestern India benefit from the sale of Prosopis fuel wood and charcoal (Tewari et al. 2000). Now, Prosopis has become an additional source of income. The utilization of the species is the best option to manage the invasion for invasion-prone lands.

\section{Conclusions}

The present study has quantified massive invasion of Prosopis juliflora in Kachchh Desert Wildlife 
Sanctuary, specifically on the fringes of Khavda and Bela islands and in the parts of little Banni in the Great Rann of Kachchh during 1977 and 2011. The study has found that the increasing spatial extent of Prosopis cover is a major threat to indigenous biodiversity and ecosystem services. The spatial database generated will be helpful in management planning in preparing strategies to control rapid invasion of Prosopis in Kachchh Biosphere Reserve. There is an urgent need to initiate national level systematic efforts to locate and map invasive plant species using remote sensing techniques towards conservation of biodiversity.

\section{Acknowledgements}

The work has been carried out under national project on 'Inventorisation and Monitoring of Biosphere Reserves in India using remote sensing and GIS technology', supported by Ministry of Environment and Forests, Government of India. Authors are thankful to Dr V K Dadhwal, Director, NRSC for encouragement and Chief Wildlife Warden and Field Director, Kachchh Biosphere Reserve, Bhuj and State Forest Department, Gujarat for facilities to carry out the field work.

\section{References}

Anderson G L, Everitt J H, Richardson A J and Escobar D E 1993 Using satellite data to map false broom weed (Ericamera austrotexana) infestations on south Texas rangelands; Weed Technology 7 865-871.

Anonymous 2005 Kachchh Biosphere Reserve; State Forest Department, Gujarat, India.

Berg E C V, Kotze I and Beukes H 2013 Detection, quantification and monitoring of Prosopis in the Northern Cape Province of South Africa using remote sensing and GIS; South African J. Geomatics 2(2) 68-81.

Bhatt G D, Kushwaha S P S, Nandy S and Bargali K 2013 Vegetation types and land uses mapping in south Gujarat using remote sensing and geographic information system; Int. J. Adv. Remote Sens., GIS and Geography 1(1) 20-31.

Champion H G and Seth S K 1968 The revised forest types of India; Government of India, New Delhi.

Chavez P S 1996 Image-based atmospheric correctionsrevisited and improved; Photogramm. Eng. Remote Sens. 62(9) 1025-1036.

Congalton R G and Green K 1999 Assessing the accuracy of remotely sensed data: Principles and practices; Lewis Publications, Boca Raton, FL, USA.

FAO 1998 Prosopis species in the arid and semi-arid zones of India; http://www.fao.org/docrep/006/ad321e/ ad321e03.htm.

Getachew S, Demissew S and Woldemariam T 2012 Allelopathic effects of the invasive Prosopis juliflora (Sw.) DC. On selected native plant species in Middle Awash, Southern Afar Rift of Ethiopia; Manag. Biol. Invasions 3(2) 105-114.
Goslee S C, Havstad K M, Peters D P C, Rango A and Schlesinger W H 2003 High-resolution images reveal rate and pattern of shrub encroachment over six decades in New Mexico, USA; J. Arid Environ. 54 755-767.

GUIDE 1999 Ecorestoration of Banni grassland; Gujarat Institute of Desert Ecology, Bhuj, 79p.

IUCN 2009 Guidelines on Biofuels and Invasive Specie; Gland, Switzerland: IUCN, 20p.

Jadhav R N, Kimothi M M and Kandya A K 1992 An approach for assessment of grassland using satellite remote sensing - A case study for semi-arid region (Banni), Gujarat; Proc. Nat. Symp. Remote Sens Sustainable Development, pp. 37-42.

Joshi C, Leeuw J D and Duren I C V 2004 Remote sensing and GIS applications for mapping and spatial modelling of invasive species; Proc. ISPRS 35 669-677, http://glcf. umd.edu/research/portal/geocover/.

Lamb D W and Brown R B 2001 Remote-sensing and mapping of weeds in crops; J. Agri. Engg. Res. 78 117125.

Landis J R and Koch G G 1977 The measurement of observer agreement for categorical data; Biometrics 33(1) 159174.

Langley S K, Cheshire H M and Humes K S 2001 A comparison of single date and multitemporal satellite image classifications in a semi-arid grassland; J. Arid Environ. 49 401-411.

Lymburner L, Beggs P and Jacobson C R 2000 Estimation of canopy average surface specific leaf area using Landsat TM data; Photogramm. Eng. Remote Sens. 66 183-191.

Mitsuda Y and Ito S 2011 A review of spatial-explicit factors determining spatial distribution of land use/land-use change; Landscape Ecol. Eng. 7 117-125.

Mooney H A and Drake J A 1987 The ecology of biological invasions; Environment 29(5) 12.

Muthana K D and Arora G D 1983 Prosopis juliflora (Swartz) DC, a fast growing tree to bloom the desert. CAZRI Monograph No. 22. Central Arid Zone Research Institute, Jodhpur, India, 19p.

Pasiecznik N M, Felker P, Harris P J C, Harsh L N and Cruz G et al. 2001 The Prosopis juliflora-Prosopis pallida Complex: A Monograph; Coventry, UK, HDRA.

Puyravaud J P 2003 Standardizing the calculation of the annual rate of deforestation; For. Ecol. Manag. 177 593-596.

Reddy C V K 1978 Prosopis juliflora, the precocious child of the plant world; Indian Forester 104 14-18.

Reddy C S 2008 Biological invasion: Global terror; Curr. Sci. 94(10) 1235.

Reddy C S, Pattanaik C and Murthy M S R 2007 Assessment and monitoring of mangroves of Bhitarkanika Wildlife Sanctuary, Orissa, India using remote sensing \& GIS; Curr. Sci. 92(10) 1409-1415.

Robinson T P, Klinken R D V and Metternicht G 2008 Spatial and temporal rates and patterns of mesquite (Prosopis species) invasion in western Australia; J. Arid Environ. 72 175-188.

Sastry K L N, Thakker P S and Jadhav R 2003 Biodiversity threat through exotic species monitoring and management using remotely sensed data and GIS techniques - A case study of Banni (Kachchh) Gujarat, India; 6th annual international conference on MAP INDIA 2003 during 28-31 January 2003, New Delhi.

Saxena S K and Venkateshwarlu 1991 Mesquite an ideal tree for desert reclamation and fuel wood production; Indian Farming 41 15-21.

Shah J and Somusundaram S 2010 Preliminary GIS and remote sensing analysis on Banni grasslands, Kachchh; Prajna - J. Pure Appl. Sci. 18 15-17. 
Tessema Y A 2012 Ecological and economic dimensions of the paradoxical invasive species - Prosopis juliflora and policy challenges in Ethiopia; J. Econ. Sustain. Dev. 3(8) $62-70$.

Tewari J C, Harris P J C, Harsh L N, Ladoret K and Pasiecznik N M 2000 Managing Prosopis juliflora (Vilayati babul): A technical manual; CAZRI, Jodhpur, India and HDRA Conventry, UK, $96 \mathrm{p}$.
Venugopal G 1998 Monitoring the effects of biological control of water hyacinths using remotely sensed data: A case study of Bangalore, India; Singapore J. Trop. Geogr. 19(1) $92-105$.

Wittenberg R and Cock M J W 2001 Invasive alien species: A toolkit of best prevention and management practices: CAB International; Wallingford, UK.

Xie Y, Sha Z and Yu M 2008 Remote sensing imagery in vegetation mapping: A review; J. Plant Ecol. 1(1) 9-23.

MS received 31 January 2014; revised 13 May 2014; accepted 15 May 2014 